\title{
HISTORIOGRAPHY BY OBJECTIVES: A NEW APPROACH FOR THE STUDY OF HISTORY WITHIN THE FRAMEWORK OF THE PROPOSED TWENTY-FIRST CENTURY SCHOOL OF HISTORIOGRAPHY
}

Sujay Rao Mandavilli

Email: sujayrao2012@gmail.com

\begin{abstract}
The paper presents a broad overview of various approaches adopted in the field of historiography across the ages starting from ancient times. It also discusses the merits and demerits of the major schools of thought and proposes a new methodology for the study of history within the framework of the proposed Twenty-First Century school of Historiography. This paper proposes a stakeholder-focussed approach towards historiography and encompasses a wide range of topics from research and definition of processes to dissemination of information to multiple stakeholders, and comprises a large number of checks and balances to prevent potential misuse of history or a one-sided interpretation of history. It also proposes a wide-range of heuristic tools to aid the researcher in carrying out his research and emphasizes objective and data-driven approaches throughout. It seeks to lay a greater emphasis on the roles and responsibilities of a historian from the point of view of the twenty-first century. The key objective of this paper is to ensure that the historian avoids the pitfalls of all ideology-driven approaches and acts in the greater interests of science, society and the education system, and that as many checks and balances as possible are put in place. We seek to reiterate that in the glamorous era of science and technology, the role of a historian can only become much more purposeful and exciting and can encompass completely new vistas of research and historiography. Although these approaches stem from the author's research experience in Ancient India, the approaches and principles of Historiography can be put to use anywhere in the world.
\end{abstract}

\section{Introduction}

\section{What is historiography?}

The term historiography refers to a body of historical work on various topics. It also refers to the art and the science of writing history. Historiography may be defined as "The history of history". Historiography is usually defined and studied by topic, examples being the "Historiography of the French Revolution," the "Historiography of the Spanish Inquisition," or the
"Historiography of Ancient India". Historiography also encompasses specific approaches and tools employed for the study of history. The direction of research in the field of historiography has broadened and changed over time, starting from traditional view of history as a mere narrative of events to Marxist historiography and post-modern schools of historiography. In recent decades, there has been an interest in formulating newer approaches, particularly in areas such as 


\section{2 \\ ELK \\ Asia Pacific Journals \\ $\underline{\text { www.elkjournals.com }}$}

cultural studies, and the field is set for a major revitalization with a plethora of new approaches and techniques.

Furay and Salevouris (1988) define historiography as "the study of the way history has been and is written - the history of historical writing... When you study 'historiography' you do not study the events of the past directly, but the changing interpretations of those events in the works of individual historians." 1

\section{Definition of history}

Some of the earliest definitions of history were given by the Greeks and the Romans. Let us now proceed to examine some definitions of history given since ancient times. According to Dionysius of Halicarnassus, history had to contain the quintessence of human experience which provided universal values for civilization. Aristotle defined history as "The manifestation of human nature, intentions and motives over the millennia which differed in degree and not in their basic nature." According to Henry Johnson, "History is at a broad level, a summary of everything that has ever happened". According to Thomas Carlyle, "History is nothing but the biography of great men, and is a record of human accomplishment". According to Lord Acton, "history is a story

1 Conal Furay and Michael J.Salevouris: The methods and skills of writing history._A Practical of the unfolding march to freedom". This idea was accepted by Turgot and Condorcet as well. According to A.L. Rowse, "history is a record of the life of men in their geographical and physical environment". According to Seignbos, "History is a science of reasoning." According to Ernest Bernheim, "History is a science that investigates and presents in their context of psycho-physical causality the facts determined by space and time of the evolution of men in their individual as well as typical and collective activity as human beings." According to Rousseau, "History is the art of choosing from the many lies, one which most closely resembles the truth." According to Benedetto Croce, "All history is one supreme spirit which is indivisible, but has four different aspectsart, ethics, logic and economics- which emerge from the basic unity of the spirit." According to John Findlay, "History is any sequence of events traced in their relations." According to Professor Maitland, "History is what people have done and said, above all what they have thought." According to G.J Renier, "History is the story of men living in societies, in which group activity, collective response to creative thoughts and sociability and will to serve society and act in the greater interests of common good, is of paramount importance." According to

Guide. 3rd ed. Wheeling, IL: Harlan Davidson, Inc., 2010. 


\section{2 \\ ELK \\ Asia Pacific Journals \\ $\underline{\text { www.elkjournals.com }}$}

G.R. Elton, "History is concerned with all those human beings, sayings, thoughts, deeds and sufferings which have occurred in the past and have left present deposits and it deals with them from the point of view of constant change. "According to Belgian Historian Henri Pirenne, "History is the story of men living in societies and their deeds." Like Hegel and others, who insisted on the role of great men in history, Thomas Carlyle argued that history was the biography of a few central individuals, heroes, arguing "The history of the world is nothing but the biography of great men." According to John J. Anderson, "History is a narration of the events which have happened among mankind, including an account of the rise and fall of nations, as well as of other great changes which have affected the political and social condition of the human race." 23456

\section{Approaches to historiography}

We will now briefly describe various schools of historiography since ancient

\footnotetext{
${ }^{2}$ (originally: Geschichte ist ... ein Dialog Zwischen Gegenwart und Vergangenheit.) - Edward Hallet Carr. 1961. What Is History? New York: Vintage Books.
}

\footnotetext{
${ }^{3}$ History: Its theory and its method B.Sheik Ali Second Edition McMillan
}

times beginning with the Greeks in the $6^{\text {th }}$ Century BC.

\section{Ancient historiography}

In ancient times, the first history was written by Ephorus (4th century BC) who was a disciple of Isocrates. This work has been lost, but its influence can be seen in the works of his son Demophilus, Polybius (203-120 BC) and Diodorus (1st century BC) who gave comprehensive accounts of their worlds. Heredotus is considered by many to be the father of historiography. It is believed he largely drew his inspiration from Hecataeus of Miletus. He is noted for his fast-paced style of writing, ability to engage readers, and his first-hand accounts of events. Poets like Homer and Hesiod also wrote poems with historical content. Thucydides also contributed greatly to historiography. Although he was not as famous as Herodotus, he was known for his thoroughness of approach, his deep analysis of events and his accuracy and his ability to construct and derive general principles from an analysis of historical data. Posidonius and Polybius were other Greek

\footnotetext{
${ }^{4}$ Concepts and Methods of Historiography Dr K'L Khurana Lakshmi Narain Agarwal Publications, 2006

${ }^{5}$ An introduction to Historiography Bikash Bhattacharya 2011

6 John J. Anderson. 1876. A Manual of General History.
} 


\section{2 \\ ELK \\ Asia Pacific Journals \\ $\underline{\text { www.elkjournals.com }}$}

historians. Greek Historiography is known for its rational and meticulous approach. Fabius Pictor was the first Roman historian, who laid the foundation for Roman historiography. Cato the Censor was the greatest of early Roman historians, who rose from a very humble back ground to become one of the greatest Historians of all times. Livy, Cornelius Tacitus and Antipater were other great historians of Rome. Roman historiography borrowed heavily from the Greeks, but was less analytical in approach and often lacked in rigour and depth.

\section{Medieval, Enlightenment and Post- Enlightenment Historiography}

Arab Historiography predates Islam, but was revitalized after the advent of Islam and made and attempt to reconcile Greek method and Church historiography. Historiography made steady progress during this era and Islamic scholars introduced new techniques such as Isnad. Great Islamic scholars were Ibn Khaldun, Waqidi and Al-Madaini. Church historiography also made great progress during this era, and brought new philosophical interpretations to history. Noted church historiographers were St. Augustine and Salvian. Enlightenment historiography lasted from the 1600's to the 1800 's reflected the vast changes brought

\footnotetext{
${ }^{7}$ Companion to Historiography Edited by Michael Bentley, Routledge, London and New York 1997
}

about in that era and was characterized by pragmatism and economic emancipation through historiography. Bolingbroke, Bentham, Macaulay, Voltaire, Montesquieu and Mill belonged to this school. Towards the end of this era, there was a renewed interest of histories of countries such as India owing to colonialism and expansionism of European powers. However, such scholarship was not entirely free from racism and colonial prejudices. Noted English Historians of this era included Edward Gibbon and Thomas Carlyle. Later English historians included Henry Thomas Buckle and Arnold Toynbee. ${ }^{7}$

\section{German school}

The German school of historiography has left a profound impact on the modern world. Hegel was one of the German philosophers of this age. His concept of dialectics, which also meant discussion, was an idea where a reconciliation between thesis and anti-thesis led to synthesis. This idea influenced Karl Marx greatly and one of the key tenets of Marxism and Marxist historiography, though in greatly modified form. Ranke was another great German historiographer who played a major role in bringing a scientific method to historiography, and contributed greatly to philosophy as well. Karl Marx was a great 


\section{2 \\ ELK \\ Asia Pacific Journals \\ $\underline{\text { www.elkjournals.com }}$}

thinker and philosopher, and also one of the most controversial men in history. While he may have had a large number of detractors, both in his time, and after, few will deny that he was one of the most influential men ever, and that his ideas had a profound effect in shaping the course of history. He embraced Hegel's dialectics, but with a twist. For Marx, most problems could be explained in material or economic terms, and this concept is known as Historical Materialism. According to Marx, nonmaterial aspects of human existence such as art, literature and philosophy were merely determined by economic factors of conditions. Marx's ideas on history were followed by many parts in the world, including in many countries which did not consider themselves to be communist or socialist. Marxist historians who do not subscribe to mainstream Marxist philosophy call themselves 'marxist' (starting with an ' $\mathrm{m}$ ' in lower case), while those who do call themselves 'Marxist' (starting with an ' $\mathrm{m}$ ' in upper case). Marxist historiography has made contributions to the history of the working class, oppressed nationalities, and the methodology of history from below. Few would deny that Marx was highly criticised both in his life time and after, both for his ideas on

\footnotetext{
${ }^{8}$ Peter Burke, French Historical Revolution: The Annales School 1929-89 (1990), Polity Press
}

economics and history, and criticisms of his philosophy and historical methods have been many.

\section{Modern trends in historiography}

Major changes have occurred in the field of historiography since the time of Karl Marx, and the field is still constantly evolving and changing to encompass newer vistas and horizons. We now discuss some of the major changes that have taken place in the field of historiography since the field of Karl Marx. In recent times, history has been seen as more of a science than an art. An emphasis has been made on its interrelationship with Geography, Economics, Sociology, Psychology, Archaeology, Anthropology, Philology and other sciences. It has also been used as a tool to draw lessons from the past, analyse events scientifically and to predict future events. Scholars such as Prof E.H. Carr, Vico, Collingwood, Comte, Spengler and J.B.Bury have also supported the view that history is a science. The Annales ${ }^{8}$ School has been influential in setting the agenda for historiography in many countries, and has helped incorporate social scientific methods into history, with an emphasis on social themes over political themes, and an amalgam with Marxist thought. 


\section{2 \\ ELK \\ Asia Pacific Journals \\ $\underline{\text { www.elkjournals.com }}$}

New trends in historiography also include Cliometrics, Comparative history Cultural history, Cultural history, history of art, history of literature, subaltern history or history from below etc.

\section{Nationalist historiography in India}

The Indian Nationalist School of historiography arose from the desire to set right alleged biases and prejudices in Colonial historiography particularly in the works of English scholars such as James Mill $^{9}$ who were hostile to India. It also arose from the desire to search for a national identity and displace the colonial mind set. One of the progenitors of this school was Bankim Chandra Chatterjee.

The Indian nationalist school of historiography, on the other hand, was accused of being over-reactionary, and as a result of its innumerable flaws which also included methodological ones, had never made much headway in forging a broad consensus among a wide range of scholars. In addition, R.C. Majumdar and other Nationalist historians were often accused of Hindu nationalism and communalism. They were also accused of trying to glorify India's past and lacking objectivity, consistency of method and rigour. It was also accused of being casteist, and lacking

\footnotetext{
${ }^{9}$ Mill, James (1817), The History of British India (1 ed.), London: Baldwin, Cradock, and Joy
}

a subaltern perspective. However, nationalist historiography has greatly contributed to the study of India's cultural history. It has also contributed to the study of regional cultures. ${ }^{10}$

\section{Hindutva interpretations of history}

At the very outset, few will deny that Hindutva approaches cannot hold up to rigorous scholarly scrutiny, and most would not qualify as bona fide approaches at all, being largely driven by ideological constraints such as the Hindutva desire to maintain that 'Aryans' were natives of India or to prove that the Vedic culture was older than the IVC, and is known for its casuistry and sophistry. Among their more publicized and hackneyed strategies is a criticism of a long-abandoned theory known as the 'Aryan Invasion theory' with a view to replace them with ideologydriven constructs such as the 'Vedic Indus theory', 'Indigenous Aryan theory', or in some cases even the 'Out of India theory'. Although many colonial constructs are still in use well into the twenty-first century, Hindutva approaches, unlike those of the Indian nationalist school, may not be just reactionary or ill-conceived; they may, in certain cases, be even full of dubious and convoluted logic and paralogisms used to push a certain point of view even if it has

10 D. Gaur, Essays in History and Historiography, Anmol Publications, New Delhi, 1995 


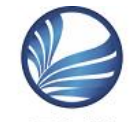

ELK

Asia Pacific Journals

www.elkjournals.com

little mainstream or intellectual backing. Hindutva approaches can also be identified through their polemical constructs and their minatory posturing, and Hindutva forces had nearly managed to wrest control of key institutions in India in the early 2000's. The author has discussed Hindutva strategies in great detail in his papers on the 'Aryan problem' published by the ICFAI University press. Any twenty-first century approaches to historiography will need to take into account the importance of countering such ideologically-driven approaches and interpretations of history. ${ }^{11}$ 12

\section{Post-colonialist historiography in India}

Post-colonial historiography emerged as a reaction towards the colonial world-view and sought to emphasize a multi-polar world as opposed to a euro-centric standpoint, and rescue objectivity from the debilitating effects of colonialism. However, this school has been criticized for its lack of historical method and its association with nationalist movements in some countries. The leading postcolonial theorists are Frantz Fanon, Edward Said,

\footnotetext{
${ }^{11}$ Syncretism and Acculturation in Ancient India: A new Nine Phase Acculturation Model explaining the process of transfer of power from the Harappans to the Indo-Aryans Part One Sujay Rao Mandavilli, ICFAI Journal of History and Culture, 2009
}

Gayatri Spivak, Homi Bhabha, and Leela Gandhi.

\section{Subaltern historiography in India}

Subaltern historiography emerged in India in the 1980's as a distinct discipline of study. Vivek Chibber and Vinay Lal have been key proponents of Subaltern studies. The key tenet of Subaltern history is to look at history from the point of view of the elites and the downtrodden. Vivek Chibber has also been associated with the 'New left' which is trying to make Marxist historiography more relevant for the times.

\section{Post-modernist Historiography in India}

Post-modernist historiography is still in a nascent stage in India. Post-modernism emphasizes a greater or enhanced role of a historian towards society by emphasizing a humanistic outlook. It also encourages a search for new topics for analysis, and encourages a sceptical outlook. Postmodernist historiography has been criticized for its vagueness of approach, and its inability to offer tangible leanings to other disciplines of study. Notable critics of

\footnotetext{
${ }^{12}$ Syncretism and Acculturation in Ancient India: A new Nine Phase Acculturation Model explaining the process of transfer of power from the Harappans to the Indo-Aryans Part Two Sujay Rao Mandavilli, ICFAI Journal of History and Culture, 2010
} 
post-modernism have included Alan Sokal, and most Marxist scholars.

\section{Marxist historiography in India}

Marxist historiography is a by-product of Marxist economic and political thought which had a great impact in the nineteenth and twentieth centuries. Marxist historiography is based on certain core principles such as Historical materialism, Dialectical Materialism and Teleological determinism. Marxist historians both in India and elsewhere have made contributions to subaltern studies and the history of the oppressed. Marxist historians have also greatly contributed to the containment of Hindutva and ideologydriven approaches. D.D Kosambi was one of the first great Marxist historians of India. Given the profound impact Marxist historiography has had over the years, both in India and elsewhere, it be necessary to discuss some of the drawbacks attributed to Marxist historiography by other mainstream researchers. Some of the common drawbacks of Marxist historiography are presented below:

\section{Historical materialism}

Historical materialism is an approach to the study of society, economics, and history, formulated by Karl Marx. Marxist

\footnotetext{
${ }^{13}$ Karl Marx, Preface to A Contribution to the Critique of Political Economy
}

Historical materialism looks for the causes of changes in human societies and places an emphasis on material and economic factors in driving changes in society and the centrality of social class and economic constraints in determining historical outcomes. The fundamental premises of historical materialism are given below:

'The Mode of Production in material life d etermines the general character of the socia 1, political, and spiritual processes of life. I $t$ is not the consciousness of men that determines their existence but on the contrary, their social existence that determines their consciousness.' 13

Engels sums it up very succinctly as below: "Mankind must first of all eat, drink, have shelter and clothing, and therefore work before it can pursue politics, science, art, religion etc. The economic production and the structure of society of every historical epoch necessarily arising therefrom constitute the foundation for the political and intellectual history of that epoch, that consequently (ever since the dissolution of the primeval communal ownership of land) all history has been a history of class struggles, a struggle between exploiters and exploited, between dominating and dominated classes at various stages of social development; that the struggle, 


\section{2 \\ ELK \\ Asia Pacific Journals \\ $\underline{\text { www.elkjournals.com }}$}

however, has now reached a stage where the exploited and oppressed class (the proletariat) can no longer emancipate itself from the class which exploits and oppresses it (the bourgeoisie) without at the same time forever freeing the whole of society from exploitation, oppression, and class struggles."

Thus, Marxists believe that humans must produce the necessities of life like food, clothing and shelter, water, before they can think of things like arts and literature. Marxism emphasises Dialectical materialism as opposed to the Dialectical idealism of Hegel.

The idea of Historical Materialism has been developed on by many other such as Leon Trotsky, Vladmir Lenin, Mao Zedong, Eduard Bernstein, Karl Kautsky, Georgi Plekhanov, Nikolai Bukharin and others. While Eric Hobsbawm and other scholars have stressed that an interpretation of Historical materialism in narrow context would be incorrect (this position was asserted in a letter by Engels to J. Bloch in 1890 too), few would deny that In Vulgar Marxism, economic factors take precedence over other factors, and this was admitted to by Indian Marxist historian K. N. Panikkar also in an interview with the popular press. This leads to Marxist historians leaving out areas like cultural

\footnotetext{
${ }^{14}$ Eric Hobsbawm, 'On History' Weidenfeld and Nicolson 1997
}

studies, for example, which would be crucial in battling religious dogma in countries like India. Such approaches invariably lead to one-sided interpretations. 14

\section{Teleological and deterministic approach of Marxist historiography}

Another problem with Marxist historiography is its teleological or deterministic approach towards historiography. According to Marxism, society is governed by certain laws which drive it towards a certain destiny which is pre-determined. Nothing can illustrate this more aptly than the statement "What the bourgeoisie produces above all, is its own gravediggers. The expropriation is brought about by the laws of capitalist production and the centralization of the means of production and socialization of labour reach a point where they prove incompatible with their capitalist husk. The husk bursts asunder. The knell of capitalist private property sounds. The expropriators are expropriated. In place of the old bourgeois society, with classes and antagonisms, we shall have an association in which the free development of each is the condition for the free development of all." 15 (Mazlish: 1984, p. 105)

\footnotetext{
${ }^{15}$ Bruce Mazlish, 'The meaning of Karl Marx', New York, Oxford University Press
} 
Marxist historiography, is a tool to be used in line with its historiographical principles and objectives. It assumes without much discussion and ado, that communist society is a utopian paradise, and disenchantment with the ills of capitalism will automatically lead to communism. It also ignores human aspects, such as desire of man to dominate, the existence of petty politics and rivalries, the fact that rivalries in non-communist societies would actually help maintain a balance of power, and falsely assumes communism would be a solution to all the ills of capitalism. He never predicted the totalitarian aspects of communism. The details of the structure and the inner workings to the proposed classless society were scarcely provided by Marx, and Marx's ideas were idealistic, utopian and half-baked. This does give the scholar a temptation to base his work on false assumptions, and the quality of analysis provided by a historian would diminish somewhat. A scholar, blindly believing the tenets of an approach, may tend towards erroneous conclusions. Marxist historians around the world have tended to exhibit dangerous tendencies such as their vilification of pre-communist societies and glorification of communist societies and an ideologically-driven discrimination between various periods in history.

\section{Reductionism}

Another criticism of Marxism or a rigid interpretation of Marxism has been reductionism. Thus, an entity is expressed primarily as a sum of its constituent parts, and the interactions between them, and this combined with Marx's Historical materialism would lead to the historian making very simplistic and naïve assumptions, greatly compromising on the quality of research.

\section{Simplistic or erroneous compartmentalization of phases in human history}

Another serious criticism is Marx's Simplistic notions of phases human history which he claimed were Primitive Communism, Feudalism, Capitalism, and Communism, but evidence has not always borne this out. It is claimed that the earliest human societies were classless societies based on co-operation and co-existence and devoid of frictions, but this may not have been the case at all. This statement may not be backed up by adequate data, as history as we know it did not come into existence until later. We do not know if savage societies in the Stone Age were classless, and if they were relatively classless they were so perhaps because they were less complex, and because the concept of personal wealth as we know it today, may not have existed. To put it in Marx's words 'Production relations' were less complex. Even then, it was likely that clans, leaders, exploitation 
and barbaric cruelty existed even then. Even a relatively egalitarian society like that Indus valley civilization, which may not have had exploitation as we know it, had classes. Class stratification in contemporary civilization was more pronounced, and a caste system existed in Post-Harappan India. Marx's theory does not take into account man's competitive spirit and desire to dominate. With hindsight, exploitation manifested itself in its ugliest forms in communist societies, and Marx's stages of human evolution may be an over-simplified, one-size-fits-all approach. The term capitalism is itself a very nebulous term and compartmentalizing various types of societies such as the USA, Sweden and Malaysia into one broad category called capitalism may be an over-generalization. A Marxist historian, while using such an over-simplified approach may run the risk of committing grave errors in analysis. Also, the transition from a class society to a classless society may not always happen the way Marx envisaged it. This may happen, for example through legislation or reform, or through change in the nature of labour, or though better awareness or education. Again, most of Marx's prophecies failed to materialize.

\footnotetext{
${ }^{16}$ The Eighteenth Brumaire of Louis Bonaparte, Karl Marx, 1852 p 15
}

\section{Ignores the role of individuals in shaping history}

Another important topic of debate would be the role individuals play in shaping human destiny. Some ideology-bound Marxist scholars have shied away from the role played by individuals in shaping human destiny. However, Engels and Marx have had a completely different explanation. According to Marx, ${ }^{16}$

"Men make their own history, but they do not make it as they please; they do not make it under self-selected circumstances, but under circumstances existing already, given and transmitted from the past. The tradition of all dead generations weighs like an Alp on the brains of the living. And just as they seem to be occupied with revolutionizing themselves and things, creating something that did not exist before, precisely in such epochs of revolutionary crisis they anxiously conjure up the spirits of the past to their service, borrowing from them names, battle slogans, and costumes in order to present this new scene in world history in time-honoured disguise and borrowed language. Thus Luther put on the mask of the Apostle Paul, the Revolution of 1789-1814 draped itself alternately in the guise of the Roman Republic and the Roman Empire, and the Revolution of 1848 


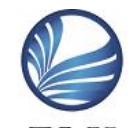

ELK

Asia Pacific Journals

www.elkjournals.com

knew nothing better to do than to parody, now 1789 , now the revolutionary tradition of 1793-95. In like manner, the beginner who has learned a new language always translates it back into his mother tongue, but he assimilates the spirit of the new language and expresses himself freely in it only when he moves in it without recalling the old and when he forgets his native tongue."

Marxist historiography takes the ideal or pre-defined driving forces which are assumed to operate under all circumstances as ultimate causes, instead of investigating what is behind them. There is no formal study to understand the motives of men who played a major role in shaping history and the factors that drove these men to act the way they did. Thus, the standard criticism has been that Marxist historians have ignored the history of leaders and great men in shaping human history. In other words, Marxist historians have ignored political history, and to put it in their own words, "the rise and fall kings". However, in reality, such figures were influential and changes have usually been brought about due to an interplay between the actions of such men and the economic and social structure of societies. Marxist historians have once again succumbed to a one-sided interpretation of history. Paradoxically, no society perhaps glorified individuals to the extent communist societies did, the history of communist countries was often dictated by a small group of individuals who were endlessly glorified and eulogized, in a manner that would not have been possible in any contemporary society, and their faults and foibles overlooked.

\section{Ignores the idea of human thought in changing history and the role of upbringing and education in changing society}

Another criticism is that Marxist historians have consistently ignored the contributions of human thought in shaping history. Such an approach would be disastrous given the major role played by science and intellectuals in shaping human history, particularly in the last few centuries or so, and intellectual freedom, talent and genius would play are major role too. The upbringing of men and the cultural context of society plays a major role in shaping history. However, this would appear to contradict the Marxist notion of Historical Materialism. Thus the Marxist version has it that man changes the world not through thought and conceptualization, but with picks, shovels, diggers, ploughs, looms and lathes. (Wolff 2003, 28). Again, the Marxist historian may run the risk of making simplistic conclusions.

\section{Does not take human and psychological factors into account}

Another criticism of Marxism is that he largely ignored the role played by human 
psychology in shaping human destiny, and this may be due to the fact that psychology was nascent during Marx's lifetime. Social psychologis ts have therefore been among the bitterest critics of Marx and his theories. As Sigmund Freud put it, "Marx argues the very questionable position that economic motives are the only ones that determine the behaviour of human beings in a society (Mazlish: 1984, p. 134)

Marx was, in the famous phrase of Jakob Burckhardt, the first of the "terrible simplif iers." Thus, Marxist ideology is restrictive and severely curtails the thinking capacity of scholars. It has been argued that it oversimplifies issues to such an extent that it ceases to be a tool for complex analysis and is more a tool for slogan-making and the acquisition of political power. Thus it has been argued that Marxism is the opium of individuals just as Marx argued that religion is the opium of the masses. Dogmatic Marxist scholars and historians also lack the ability to understand the human aspects of a problem and to carry out a comprehensive analysis. For example, while Marxist historians in India have done a commendable job in exposing the dangers of the Hindutva ideology, few will deny the fact that their ability to do a root cause analysis of the rise of Hindutva has been extremely poor. Among these are outdated colonial constructs, Dravidian ideology, and alleged Marxist bias which have undoubtedly fuelled the rise of the Hindutva. Few will deny that balanced and objective scholarship is the only way to destroy the Hindutva monster. The alleged Marxist technique of distortion or suppression, can only work in the short term, and will actually encourage and fuel Hindutva in the longer run.

\section{Limited or flawed perspective on social change}

From the point of view of a historian, it sh ould be mentioned that Marx very naively and incorrectly assumed that conditions of the 1840s woul $\mathrm{d}$ not, could not be altered in any fundame ntal way without a revolution. However, in due course, there was political reform which Marx did not foresee. For example, in 1867, for example the British Parliamen t extended the vote to the British working class as well, bringing about changes in society. In addition, he did not foresee the consumer society or technological changes. Marx's concept of class struggle is suspect , and most scholars would consider it to be a gross oversimplification. Once again, the problem $\mathrm{w}$ ith class struggle is the use of an analytic tool appropriate to a certain time period and in a specific geographical context as a universal historical concept. As a theoretical insight, the term "Class struggle" is not as much of a universal 


\section{2 \\ ELK \\ Asia Pacific Journals \\ $\underline{\text { www.elkjournals.com }}$}

historical law as it is an analysis of a specific situation. (Mazlish: 1984, p. 133) Thus, he was not free from zeitgeist. In addition, it must be stated the most of Marx's predictions did not come to pass. Another criticism would be that the Marxist historian runs the risk of trying to force-fit assumptions into other periods leading to erroneous results. A Marxist historian therefore ends up making the wrong assumptions and conclusions. Marxism reduces everything to a 'Revolution of the Proletariat' and argues that this would be the only successful agent of change.

On the other hand, changes to society can be brought about through many means such as legislation, better awareness and agitations for better working conditions or pay. Thus a Marxist historian may end up making flawed assumptions and his analyses may lack depth. Another criticism of Marxism Is that Marxism is said to be a form of epistemological absolutism and that Marxists lend themselves to absolutist certainty and uncritical, dogmatic modes of thought that do not and cannot change easily, and cannot be re-examined in the light of changed circumstances. An example of this is that the rigid compartmentalization of society into the bourgeoisie and the proletariat is suspect and can be easily falsified in today's circumstances because employees can turn into managers and entrepreneurs easily.

\section{Euro-centric approach}

Another limitation of Marxist historiography can be traced to a criticism of mainstream Marxism itself: Other than class consciousness and oppression of the working class or the proletariat by the bourgeoisie, mainstream Marxism only mentioned other forms of oppression such as colonialism, oppression of women by men and race-relations in Western countries in passing and ascribes everything very simplistically to 'modes of production' and 'class relations'. This criticism has been made by many scholars such as Jean Cohen and others. Even though Marx has been frequently criticized of Eurocentrism, and talking about other contexts only in passing- for e.g., Asiatic Mode of Production, this criticism tends to be commonly overlooked while attempting a critique of Marist Historiography in Western countries, ostensibly because this criticism did not impact Marxist-history writing in Western countries negatively. However, this criticism is by no means insignificant particularly from the point of view of a country like India, whose notions of early history were largely shaped in the west by colonial considerations, or by a narrow Eurocentric worldview. These notions should have been challenged by Marxist historians in India after independence, and in the true spirit of Marxism, but this strangely did not happen. On the other hand, they showed, throwing 


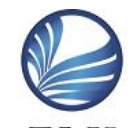

ELK

Asia Pacific Journals

www.elkjournals.com

all logic and reasoning to the winds, and only with minor exceptions such as D.D Kosambi's criticism of Asiatic Modes of production, Romila Thapar's call for abandoning the AIT in 1969 and R.S Sharma's reappraisal of the Aryan problem, a covert and overt support for imperialism, and imperialist considerations in a study of ancient India. It is baffling that nearly seven decades after independence, such antiquated narratives are still de rigour in the study of Ancient India. With minor exceptions antiquated mid-nineteenth century constructs have been the bedrock of Marxist constructs. Marxist historiography has largely played into the hands of old Occidental considerations, leave alone criticize them. This would make a complete mockery of the supposed Marxist distaste for imperialism. Marxist historiography has proven to be one of the pillars of racism and imperialism in post-independent India, so much so that the author has no qualms or inhibitions in recommending that the term 'Colonial-Marxist-Imperialist school of Indology' be brought into use. This onesidedness was one of the factors responsible for the rise of Hindutva fascism in the 1990's, and has, in addition, hampered the progress in many a field of science: we will even argue that this approach is at least to some extent anti-science, anti-knowledge and anti-truth. A case in point in the Marxist opposition to Post-Colonial history. We have discussed colonial considerations in ancient Indian historiography, in some level of detail in our papers pertaining to the Aryan Problem and the Identity of the Harappans, and have already drawn our readers attention to the vast literature available on the subject, and readers, including those who do not consider Ancient India to be a focus area of their study, are strongly encouraged by the author to familiarize themselves with the forces shaping the study of Ancient India, as this has been the battlefield of many different ideologies. In addition to all this, labour conditions have greatly improved since the time of Marx, and better education, bargaining power of workers, labour participation in unions, besides the rise of the services industry have changed the characteristics of labour considerably, such that oppression of the proletariat may not exist in the same form as envisaged by Marx. The nature of oppression today may, on the other hand, include other controversial forms such as 'Employment at Will' which Marxists never addressed as these may not existed during his day. Thus the Marxist notion of class struggle may be termed as sclerotic, antiquated, half-baked, one-sided, rigid, and of course noninclusive has never has had the attribute of constant re-examination and reintrospection. Marxism also talks about Marxist Literary Criticism and other concepts which have a decidedly nineteenth-century tone about them. 


\section{2 \\ ELK \\ Asia Pacific Journals \\ $\underline{\text { www.elkjournals.com }}$}

Though perhaps still relevant, it has been superseded by other tools, techniques and concerns. A Marxist can therefore be easily distinguished by his tone and tenor, and his language and his approach would easily set him apart from others. One may argue that it has all the characteristics of a dogmatic religion, and has often been described as such. Scholars are well-advised to prove this using the standard principles of epistemology and in the larger interests of scholarship, to lay the matter to rest. All these attributes are then, perhaps, applicable to Marxist historians as well.

\section{Theoretical underdevelopment and a lack of a long-term strategy}

Another criticism of Marxist historians is that that they have left out many crucial areas of study such as archaeology, linguistics and have focussed only on class struggle, and did not take into account the key requirements of a region while formulating research strategies. The inability of Marxist historians to formulate any long-term strategy, or any strategy that could take into account changes in circumstances from time and could also take into consideration the overall wellbeing of society would stem from a Marxist historian's blinkered and myopic vision. This criticism has been made by none other than Social Scientist Perry Anderson, and cannot be more apt for India, where up-todate historical models have never been formulated in a way that would facilitate long-term multi-disciplinary research. Instead, we see historical models dating back to the 1850's. Cultural studies in India were neglected, and attempts were never made to address key historical issues such as the 'Aryan' problem, and study culturally crucial periods of Indian history like post-Harappan India. This is despite Romila Thapar's repeated calls to reconstruct post-Harappan history and late Marxist historian RS Sharma's publications on the thorny and contentious 'Aryan' issue. This alleged aversion may be due to several reasons (a) They don't want to abandon antiquated colonial models which are effectively impossible to sell to historyliterate populations and have never criticized the nineteenth century school of Indology or Dravidian nationalism (b) They harbour an incorrect notion that research on post-Harappan India increases superstition or blind faith (c) Marxist historians also had the wrong notion that suppression of history or a counter-ideology would contain Hindutva. (d) They do not want controversial archaeological sites to be excavated and are worried it may increase interest in post-Harappan archaeology (e) They associate this period with the caste system (However, the caste system can be researched only if Post-Harappan history is constructed) (f) Marxist historiography wants to distance itself ideologically from political history and the rise and fall of 


\section{2 \\ ELK \\ Asia Pacific Journals \\ $\underline{\text { www.elkjournals.com }}$}

kings. (g) Blind opposition to the Hindutva School to maintain political balance. (h) The fear that changes to historiography will lead to a condemnation of Marxist historiography and political ideology in general. We seek to reiterate the fact that Hindutva can be contained only through balanced and objective scholarship, and that one kind of bias would legitimize every other kind of bias. Marxist historians have claimed, when cornered, that all schools of thought have been encouraged. This is wrong because this approach will encourage Hindutva, not marginalize it. Only an ideology-free and a balanced approach will help scholars work in the interests of science and scholarship and help prevent polarization of views. The reason for this that people with vested interests only constitute a small percentage of the population. Such vested interests prey on the archetypal confounded Indian. If other scholars pursue objective approaches, they get intellectuals and other Indians on their side, marginalizing Hindutva automatically and rendering it less powerful. Even if such approaches are followed, the road towards ideology-free interpretations will perhaps be still rocky, but it will make consensus-building much easier, and will actually help decimate communalism in the long-term. Readers may make a note of the following quote for example from Marxist Historian Irfan Habib, and draw their own conclusions, "Let us look at why a historian chooses a subject. To give a very mundane example, because I had a Communist background, I chose to work on the agrarian system of Mughal India, at the same time that my friend, the late M. Athar Ali, chose the structure of nobility under Aurangzeb, because, being of a liberal persuasion, he wished to examine how far religious identities impinged on Mughal administrative functioning. We would not have chosen these different topics if our personal predilections were identical. So, even in research work, the very fact that one chooses a particular topic may reflect some previous presumptions about what is more significant in history." 17 Marxist historians have also neglected regional histories in India, and this has contributed to a feeling of alienation among certain sections of society. The correct approach would have been to encourage a study of regional histories and bring out an underlying oneness among the various cultures in the sub-continent to promote

17 THE PHILOSOPHY OF HISTORY: IRFAN HABIB JOURNAL OF HISTORY AND SOCIAL SCIENCES VOLUME: II, ISSUE I, JANUARY-JUNE 2011 


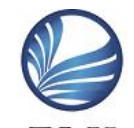

ELK

\section{Asia Pacific Journals}

www.elkjournals.com

Indian national integration without compromising factual accuracy. The approach followed by hidebound Marxist historians in India inevitably leads to a languid and a fossilized approach in the long-run and will be equated with senility and old age, and is borne out by the fact that the average age of a Marxist historian in India is around eighty years. They will act against the interests of science, society and the education system; Marxist historiography in India will invariably and inevitably collapse, and with disastrous results. This is because it has proven practically impossible to sell outdated constructs to the educated Indian public. Therefore, the Marxist approach comes with an implied foolishness, and such scholars persist with outdated paradigms irrespective of whether others believe in them or not. They have no action plan for the future. The threats to Indian society from religious fanatics will then be enormous, as we are leaving too many things open to risk. Marxist history tend to be dull, vapid and uninteresting besides being one-sided and may not focus on society's needs. This automatically leads to the alienation of the general public, and this is one scenario any twenty-first century scholar must avoid. This leads to the public looking at other options, and this naturally gives the Hindutva forces an upper hand. People do not believe in Marxist historians any more, even in circumstances where they may be right. The Hindutva forces have learnt the ability to sell their devious constructs to the public. Hidebound and dyed-in-the-wool Marxist scholars, on the other hand, lack the intelligence, the imagination and the creativity to even pass on their concerns to the next generation of Indians, and if they want to do this they must jettison their puerile and ossified approaches for pragmatism. This is somewhat analogous to the story of the boy who cried 'wolf' all the time, only to lose trust of the passers-by, have his earnest pleas for help ignored, and meet a premature and a ghastly end. Current trends such as the rise of the Hindutva, a spate in non-mainstream publications are precursors of Marxist historiography's imminent demise. In more ways than one, dogmatic Marxist historiography can be said to be one of the pillars of Hindutva. We may even refer to it as the ColonialMarxist-Imperialist school of Indology. Such approaches also work against the process of knowledge-creation, and are against the spirit of innovation. Thus, the advantages of Marxist historiography are not the same as that of Communism as an economic philosophy, which may have indeed avoided some of the evils of capitalism. What benefits did Marxist historiography bring to the table? One may be a subaltern perspective. But such perspectives can be encouraged even outside the framework of Marxist 
historiography. The second advantage may have been its ability to contain Hindutvabut this may be best termed as short-term and illusory. In the long-term such biases and antiquated approaches will undoubtedly encourage Hindutva even more. Even Edward Luce, in his book 'The Strange Rise of Modern India' ${ }^{18}$, does imply that Marxist scholarship is of questionable neutrality and the same assertion has been made by Edwin Bryant as well. Ideological interpretations of history in any form lead to a situation where critical analysis and objectivity are thrown out of the window and are replaced by politicking. Historiography ceases to be a battleground for scholars and becomes a battleground for crooks and knaves: this has disastrous consequences for India as a nation. In other words, if Marxist historians follow and ideology-driven approach, they would be setting a bad example for others to follow, and would be the root of the malaise. One even begins to wonder if these elements are really serious about tackling the Hindutva menace or whether they are only striving to protect their own interests.

\section{Historiography by Objectives or HBO}

Historiography by Objectives or $\mathrm{HBO}$ is the new approach towards Historiography proposed in this paper as a part of the proposed Twenty-first century school of
Historiography and stems from the tools and techniques employed in the Author's research publications dealing with the Aryan Problem, the Identify of the Harappans, The Indus script and literacy in Post-Harappan India. Historiography before and in the nineteenth largely century dealt with biographies, epochal events, the rise and fall or rulers or governments, and the stories of great men. The twentieth century saw a shift towards social and economic history. Likewise, we believe that the twenty-first century must witness a shift towards integrated and multi-disciplinary approaches and must not only encompass cultural studies, but must reach out to other sciences such as anthropology, genetics and linguistics as well, and must play a key role this the progress of these sciences, such that the efficacy of a historian in shaping the growth of allied sciences must become a key metric, and the raison d'etre of a historian. The distinction between arts and sciences must become blurred and must eventually vanish, except in situations where history cannot be normally considered to be a science. There must be a more international outlook albeit with a local flavour under specific circumstances. The boundaries between various periods in history, and history across regions must become blurred. One key objective of any $21^{\text {st }}$ century school must be to increase

\footnotetext{
${ }^{18}$ Edward Luce, In spite of the Gods: The strange rise of modern India, Abacus 2011
} 
levels of education and awareness in general among the masses and the historian can play a crucial role in combating superstition, dogma and blind faith by promoting a scientific view of history. We believe that stakeholders are central to the process of history-writing and will play a major role in determining the direction of historiography along with scholar-defined objectives and pre-defined or standard objectives proposed as a part of this paper.

\section{Key Processes to be followed while implementing $\mathrm{HBO}$}

\section{Identification of stakeholders}

The first step in the HBO process would be to identify stakeholders, who may vary depending on the nature and the type of the work. However, in most cases the basic list of stakeholders would be the same, and it would be unwise or unhealthy to remove any stakeholders from the standard list presented in this paper without a proper justification. An additional list of stakeholders can be prepared by identifying target audiences of a historical work and identifying users of historical information, and by trying to envisage the beneficiaries of a sound and methodical approach to history writing. This would be known as the positive list. The second approach is to prepare a list of audiences whose unhealthy activities can be mitigated by the adoption of scientific methods to history-writing.
This is known as the second list and may be referred to the negative list.

Stakeholders in the first or positive list could be

- $\quad$ Students of History

- Teachers of history

- Educationists

- The well-informed reader of history

- The layman, naïve or the man in the street, the dogmatic and the superstitious who will be greatly benefitted by a scientific approach to history

- Anthropologists whose research can be greatly enhanced by the adoption of scientific methods of historywriting

- Linguists whose research can be greatly enhanced by the adoption of scientific methods of historywriting

- Comparative historians whose research can be greatly enhanced by the adoption of scientific methods of history-writing

- Other scientists and researchers whose research can be greatly enhanced by the adoption of scientific methods of historywriting

- Stakeholders who would benefit from the resolution of unsolved problems in history. 


\section{2 \\ ELK \\ Asia Pacific Journals \\ $\underline{\text { www.elkjournals.com }}$}

- Scholar-defined stakeholders: the scholar must endeavour to add as many additional stakeholders to this list as possible by identifying users of information.

In the second list or the negative list, stakeholders could be

- Scholars, alive or dead, who follow, have followed, an ideology-driven or a one-sided approach: Religious fanatics, Nationalists, Eurocentrists etc.

- Other Scholars, alive or dead, with a narrow or vested interest, and those opposed to a multidisciplinary approach, collaborative efforts or a reconciliation of views.

- Any pseudo-scholars, alive or dead, masquerading as historians and all other forces detrimental to the healthy progress of science including scholarship of a low calibre.

- Any other approaches that would count as pseudo-science or pseudohistory and all known scholarship that would qualify as pseudohistory.

- The scholar must likewise add additional stakeholders to this list based on his target audience.

\section{Setting of Objectives}

The setting of objectives is a process that needs to be executed after discussion with various stakeholders. In certain cases, as would be the case with students of history, it would not be possible to engage in a debate with stakeholders directly. Under these circumstances, proxies, who in such a scenario, would be teachers, would need to be identified, and, may or may not be identified by the beneficiaries themselves. In case of the second list or the negative list, it would not always be possible to debate with the parties directly, and it would be necessary to take into consideration the known or innate proclivities of such parties, their past pattern of behaviour and their likely threats to society. It may also be necessary to debate with parties who are familiar with their modus operandi or their way of working. However, wherever possible, a dialectical approach may be directly adopted with such parties. Some dialectical approaches, including Reflective Equilibrium through Role Swapping (RERS) are discussed in this paper, and these have been specially formulated as the scholar may not be able to interact with a large number of stakeholders in the real world. A list of objectives will then need to be arrived at, which will mitigate the illeffects of such approaches. Reversal techniques may also be used if required, and scholars can explore situations that will increase dissatisfaction and then mitigate them. In addition to this, we propose a list 


\section{2 \\ ELK \\ Asia Pacific Journals \\ $\underline{\text { www.elkjournals.com }}$}

of standard objectives, which can be used in addition to scholar-defined objectives, as applicable. If all this appears to be motherhood and apple pie to sceptics, they are welcome to evaluate whether current approaches take all these objectives into consideration, and whether they are sufficiently ingrained into the approaches followed by the archetypal historian.

\section{Standard objectives}

The standard objectives proposed as a part of this paper are presented below. Some of these objectives can, in turn, be used to generate more scholar-defined objectives, as should be obvious to the reader:

1. To swear allegiance to the truth at all times: intellectual honesty and objectivity are of paramount importance in any endeavour, and would be the cornerstone of any historian's approach.

2. To strive towards accuracy and precision. For further details on what constitutes accuracy and precision, see Footnote 1.

3. Insistence on hard or irrefutable evidence and data wherever possible, to back up all findings. In certain cases, however, a compromise is in the best interests of scholarship particularly if key or otherwise useful and potentiallycorrect information has to be omitted due to want of irrefutable data, and if scholarship is likely to suffer as a result.
In such a case, qualifiers may be added. The approach in this paper promotes empiricism over Historical Materialism. For further details, please refer Footnote 2.

4. To work towards the greater good of society, and act in the interests of science and strive towards the enhancement of scientific knowledge. This will be one of the key objectives of any scholar, and any scholar would be advised to take this seriously. This may be referred to the scholar's social responsibility and he must never waver from this principle and adhere to it steadfastly. One example of this is that a critique of other scholars' research must be done responsibly and constructively keeping in mind the greater interests of society. Social responsibility is another key principle of this approach.

5. To always keep stakeholder interests in mind and work towards furthering stakeholder interests.

6. To work towards a stakeholder-friendly approach to history-writing, and stakeholders may vary on a case to case basis.

7. To enable and facilitate a synthesis with various fields of science, and to follow a multi-disciplinary approach wherever possible: This should be one of the core objectives of a $21^{\text {st }}$ century historian. Inter-disciplinary approaches or IDA’s, 


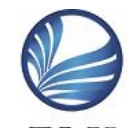

ELK

Asia Pacific Journals

$\underline{\text { www.elkjournals.com }}$

are a key part of this paper. To quote H.C.Darby, "History is the central social science, of which all others must feed. It is the basis of social sciences just as mathematics is to natural sciences."

8. To proactively work towards solving unresolved issues in science and history and to facilitate an environment where vexatious problems in science and history can be solved. Wherever there are a large number of unresolved issues, it would be necessary to identify the importance of the resolution of such issues to the advancement of science, and by adopting techniques such as an Opportunity Loss Approach or OLA and Social Benefit Analysis or SBA so that a prioritization is possible.

9. To strive towards evidence-based and objective revisionism and only where revision becomes necessary, and to denounce and combat ideology-driven revisionism and revisionism driven by vested interests. See footnote 3.

10. To work towards elimination of narrow parochial interests and vested interests in scholarship. To create a spirit of bonhomie and camaraderie in research and foster better understanding between groups. To guard against intellectual elitism and work towards the democratization of science and the dissemination of knowledge. Making public the data, the methodology used in research, and the key arguments, as far as possible.

11. To work towards the creation of a peerreview mechanism in the field of historiography by forging healthy partnerships with other scholars. It is also necessary that peer review be done as early as possible to mitigate the illeffects of shoddy scholarship. As a thumb-rule, a faulty piece of work should not normally fall into the hands of a party who is not equipped to, or does not in the normal course of events, review or critique such work. As a metric, QEPIS or Quantification of the effects of poor or Ideologically-driven scholarship (i.e. Downstream and adverse effects of poor, ideologicallydriven scholarship or the continued persistence of antiquated approaches) may be calculated from time to time including its bearing on other sciences and on society. This is one of the key requirements of this approach, and may become an area of study in itself.

12. To work, in the longer-term towards the formalization and improvement of processes which can be adopted for various aspects of scholarship; this would encompass various activities from the time, new evidence is discovered, a new topic is taken up for research, or a new hypothesis is formulated, review and examination of hypothesis, debate and dialogue until 


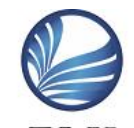

ELK

Asia Pacific Journals

www.elkjournals.com

incorporation in textbooks, including crucial checks and balances to be followed before material enters the student's presentation layer. This may be referred to as the lifecycle approach. This may be infeasible in the shortterm, as scholars of many ideological dispensations may be involved, such as religious fanatics and Marxists, for example, as in the case of India, rendering progress of any kind prima facie impossible. This can therefore best be seen as a long-term goal.

13. To constantly work towards the identification of pseudo-scientific approaches and approaches inimical to the advancement of science and scholarship throughout the lifecycle. To critique, without resorting to ad hominem attacks, pseudo-scholarship of all kinds and to work towards the quantification of bias, prejudice, and pseudo-scientific approaches at all stages in the lifecycle, and in the greater interests of society i.e. Analysis of Pseudo-scientific approaches (APSA) (This is different from QEPIS) by following standard principles of epistemology and a study of scholarbehaviour. This will need to be applied to all areas of scholarly activity such are research and peer-review, and may become a major field of study in itself. See Footnote 4.
14. To acquire competence in all allied areas, and to be up-to-date with all developments in all related fields of science.

15. To create a framework where specialists such as anthropologists, linguists, comparative historians and other scholars can carry out their research.

16. To work towards a situation where the distinction between various fields of science gets blurred.

17. To consider history as a science as work towards bridging the gap between arts and sciences in such a way that the distinction between arts and sciences is bridged to the extent possible.

18. To work towards the creation of a seamless framework so that history across regions can be studied.

19. To work towards the creation of a seamless framework so that history across periods can be studied.

20. Globalized approach: All problems and solutions must be re-examined from an international background to ensure scholarship is global in nature.

21. To combat alternative historiographies by rendering them meaningless in the long run.

22. To constantly pursue new vistas and opportunities in history writing.

23. To guard against dogma by constantly engaging in a process of self-introspection. 


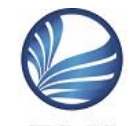

ELK

Asia Pacific Journals

$\underline{\text { www.elkjournals.com }}$

24. To analyse, any new data or evidence without undue delay and use it to review and reformulate hypotheses as applicable.

25. To never discard contradictory data that does not fit into a hypothesis. Contradictory data or evidence, on the other hand, must be welcomed, and carefully scrutinized and analysed, and a synthesis will always lead to a better solution. The scholar must also guard against simplistic solutions or solutions that do not work in the real world.

26. To guard against vindictive approaches and take what is useful from other ideology-driven approaches. For e.g. Subaltern history from Marxist historiography.

27. The criticism and elimination of restrictive approaches in other ideologies e.g. Historical Materialism to the extent it impedes science or scholarship.

28. To desist from forming any preconceived notions about the causes and effects of events i.e. thus he must refute determinism and teleology, and any restrictive notions of a covering law, and acknowledge the fact that this is one of the key differences between history and the sciences as events are often shaped by the free will of actors. This is in turn shaped by cultural and economic conditions, and also the quality of the education system and government policy, among other things. Thus, according to this approach, (a) History is shaped by the freewill of actors and this cannot be directly controlled from the point of view of this approach (b) The free will of actors is in turn shaped by positive factors and negative factors which are the focus of this approach. Examples of positive factors include a first-class and a relevant education system, facilities available for individuals to reach their full potential, a good legal framework, a good social security system and political stability. However, this list does not purport to be comprehensive and a list of positive factors must be prepared by a historian from time to time. Examples of negative factors include high unemployment, large class inequalities, poor laws or political framework, negative cultural traits in society, poor relations with neighbouring states etc. (c) Positive factors affect the freewill of individuals positively such that the carry out positive acts which further benefit society and set in motion a chain of events that is good for society (d) Negative factors tend to affect the free will of actors negatively and society may go into a downward spiral. This may be referred to effects of positive and negative forces and may be the subject of the cause and effect analysis (e) The historian must also 


\section{2 \\ ELK \\ Asia Pacific Journals \\ $\underline{\text { www.elkjournals.com }}$}

acknowledge the fact that there can be exceptions to every rule, and a denial of this crucial fact would greatly undermine a pragmatic approach. From the point of view of our approach, oversimplification is anathema. However, the historian may work towards the creation of a body of knowledge that can study the causes and effects of various events, while always leaving space to accommodate the free will of actors, and this body of knowledge and heuristic models must be continuously built upon, if the historian has to acquire greater competence in building scenarios of the future. (g) While the historian may not have control over positive and negative forces in a society, he would be welladvised to study those using historical and contemporary data. He can then collaborate with other scholars as required. These are known as Interdisciplinary approaches or IDA's from the point of view of our paper. Thus, as a possible extension of his traditional work, a historian can, based on his knowledge and database of the past, and his ability to carry out a root- cause analysis of events, work on building scenarios of the future in collaboration with non-historians. He can also partially shape it, as many concepts in this paper are aimed at such a scenario. Also refer to the Goals, Opportunities,
Extraneous factors, Strengths and Weaknesses approach (GOWEST) approach in Footnote 5 proposed as a part of this framework. This is a very powerful and a multi-faceted tool we propose to identify areas of improvement which can then be used to augment the positive forces and contain the negative ones. Thus, the historian can even act as a bridge between the past, the present and the future, and this can one day, become an exciting area of study, such that historiography becomes the basis of futurology. We may refer to this as 'Dialogue between the past, present and future' techniques, and this is a new concept in this paper. (DPPF techniques). We may draw our readers' attention to the fact that many techniques exist today that did not exist in Karl Marx's time. Examples of these are Root Cause Analysis, Causal Analysis, Back casting, Failure Modes and Effects analysis, Cross-impact analysis and Causal Layered analysis, and a historian could well do to make full use of them. Again, the historian must guard against simplistic explanations always which always undermine a better understanding of the past and must also avoid the pitfalls of reductionism. The historian may proceed to demonstrate that will a reductionist approach may work for some sciences, it may not be applicable 


\section{2 \\ ELK \\ Asia Pacific Journals \\ $\underline{\text { www.elkjournals.com }}$}

in toto to the field of historiography. As opposed to the anarchic notion that mankind does not have a destiny, it must be emphasized in our approach that destiny is made or changed through human will and effort, and this realization forms the bedrock of all DPPF techniques.

29. To look for avenues where he can impact society positively as a historian and play a role in shaping the future in collaboration with other scholars: For example, an interesting variation of DPPF techniques is to generate a list of problems in a given region or worldwide, and then use techniques in historiography to study past events and actions and approaches used in the past, including Deep History Analyses (DHA). These can then be used to provide solutions for the future. Thus, the historian can begin to play a role in shaping the future. Areas of study can include the history of drug and substance abuse, population control, female infanticide, an analysis of historical data in learning abilities in deprived children etc.

30. To understand the realities of a multipolar world and desist from adopting Euro-centric or other region-centric approach in a way that would affect his judgment or impartiality. Understanding issues from the points of view of different cultures would help a scholar broaden his horizons and act in the greater interests of scholarship. We also propose that all research teams be multi-cultural as far as practicable, and such teams must not only include specialists from various fields, but also some non-specialists as well.

31. To encourage a critical analysis of religion and constantly re-examine the role of religion in society; to work towards purging unhealthy aspects of religion using a critical analysis approach, and by acknowledging that fact that not all religions are the same. Criticism of ideology-driven discrimination between religions must be discouraged, and an evaluation and criticism of all ideology-driven approaches to historiography is encouraged, and the standard principles of epistemology must be followed to prove whether they are bona fide or not. The scholar may also contribute towards analysing and critiquing, in conjunction with other specialists in the respective fields, so-called sciences such as astrology, palmistry, Vedic mathematics, and contribute his perspective with a view to fighting pseudo-science. See Footnote 6.

32. To constantly analyse all pseudohistorical claims made from time to time such as the existence of Lemuria, the existence of Atlantis, claims of a heavier-than-air flight by Shivkar 


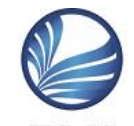

ELK

Asia Pacific Journals

$\underline{\text { www.elkjournals.com }}$

Bapuji Talpade in India in 1895, expose fraudulent claims wherever applicable and spread scientific awareness among the masses. To help a scholar achieve this, we propose a tool 'Formal Evaluation of Pre-requisites and Implications of claims' (FEPIC), where all the implications of a claim, and bearings on all other fields of study, along with a study of pre-requisites such a claim would entail, and its violation of known laws and principles are formally listed out in collaboration with other scholars, so that fraudulent claims can easily be identified and eliminated. A discussion of evidence for and against the claim may also be presented, and used in conjunction with other approaches in this paper.

33. To focus on the history of science both within a specific region, and across the world by focussing on the history of physics, chemistry, mathematics, writing systems and metallurgy to name a few, and to use such study to draw inferences and directly and indirectly enhance scientific output. We expect this would be a major area of study, and regrettably, this has been ignored largely in past approaches.

34. To participate in new areas of study such as Cliometrics which can greatly help in economic development of nations and reduce poverty and work towards bridging the gap between history and economics, and work towards combining such approaches with DPPF and other techniques.

35. To keep religious fanatics in check by facilitating higher standards in education. To constantly look for innovative ways to eradicate blind faith and superstition and fight pseudoscience by promoting scientific versions of history. To help combat superstition and blind faith by promoting scientific versions of history. See Footnote 7.

36. To adopt localized approaches wherever required. For example he can work towards better national integration and communal harmony within a region by eliminating common misconceptions, or highlighting common or shared elements of culture, or work towards better frameworks in cultural studies. This would be a legitimate and a very noble objective of a historian, provided he does not succumb to ahistorical or pseudoscientific approaches, or waver from the truth.

37. To constantly identify new research methods and new research techniques that can be of use to other historians and to take pride in his or her avantgardism. To work towards a transition from a scenario where pre-defined historical methods are followed, towards a situation where a scholar is 


\section{2 \\ ELK \\ Asia Pacific Journals \\ $\underline{\text { www.elkjournals.com }}$}

free to define his own methods (SDM's or scholar-defined methodologies), provided they do not contradict standard scientific epistemology. Thus, the scholars focus has to be to define and formulate a robust methodology against which historical methods can be evaluated. This would necessitate a paradigm shift in thinking, and may be much more complex than meets the eye, but we argue, would be the only way forward in the era of multi-disciplinary approaches, and can potentially lead to an explosion in knowledge. While this approach may be fraught with dangers, it may be necessary if greater progress is to be made, and the risks involved in an approach can be quantified and addressed either the scholar himself or by his peers in a spirit of camaraderie. If the researcher is uncertain of his approach, however, he may seek help or err on the side of conservatism by keeping it in abeyance until further scrutiny. Target audiences cannot normally be made scapegoats; if the work under consideration is a purely research-oriented publication, appropriate qualifiers may be added. Another principle to be borne in mind is that under no circumstances will a scholar restrict himself to a single approach, particularly those propounded or delineated by other scholars, especially if there is reason to believe that the approach is inadequate or insufficient, or has any known weaknesses. This is one of the key principles of this approach and would help pre-empt fossilized or dogmadriven approaches.

38. To constantly identify new objectives that can make history writing more purposeful, and seek new vistas in historiography. To prioritize objectives using Opportunity Loss approaches (OLA) and Social Benefit Analysis (SBA). In many cases, underlying problems faced by stakeholders and discovery of new evidence could also act as triggers. The former would seek to minimize the Opportunity loss while prioritizing topics for research while the latter would seek to maximize Social benefit.

39. To play a key role in conservation and preservation of historical sites in collaboration with scholars in other fields such as archaeologists by helping create awareness and through an assessment and evaluation of such sites from a historical and cultural perspective.

As some of the approaches presented in this paper are open-ended, and may in cases lend themselves to either misuse or inadequacy of interpretation, a study of the direction of research in historiography in various areas, the nature of collaboration between scholars, the issues addressed and 


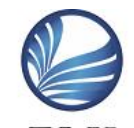

ELK

Asia Pacific Journals

$\underline{\text { www.elkjournals.com }}$

unaddressed by scholars in the absence or infeasibility of a centralized governing body may be healthy, and may become a major field of study. In addition to APSA's, this field, comprising of individual scholars, may address process-related issues as well, and process improvement methodologies, and may also be driven by metrics, which would necessitate action. For example, wide public acceptance of a patently absurd proposition or neglect of a brilliant piece of study for an inordinate length of time to the detriment of science and scholarship, would indicate that something is wrong and would normally warrant and RCA and course-corrections. Another example would be a substitution of robust or rigorous research aimed at an erudite audience with sensationalized press releases aimed at the general public. Polarization of views among scholars is another sign that intervention or augmentation of research is required. This study would also ensure that society and humans do not fall collectively into traps and pre-empt, at least in the longer-term, situations such as the near-total takeover of Indian historiography by Hindutvavaadins in the 2000's. To reiterate, the scholar has a duty towards society and the education system. A scholar in the social sciences has to act as a trendsetter and guide scholars in other sciences as well. A dogmatic adherence to one's point of view and ivorytower scholarship in the name of academic freedom may be fine, but beyond a point a reconciliation of view has to begin, and a scholars personal interests have to be reconciled with his duties towards society. As scholars have coined the term 'dialectics', why not propose and formalize 'intellectual dialectics'? it must emphasized here that scholars and intellectuals have the capacity to move towards a higher state of understanding and greatly increase the quantum of intellectual output as the technology and the research infrastructure are a far cry from what they were in the $19^{\text {th }}$ century. We may refer to this as 'Scientific Progress at the speed of light'. This is only possible is the right kind of attitudes and collaborative efforts manifest themselves in science while leaving some room for human fallibilities. The key premise of 'Scientific Progress at the speed of light' is that as the underlying infrastructure enabling a higher scientific output has been achieved due to major technological advances, this must translate into a much higher quantum of scientific output accompanied by the necessary checks and balances, and bottlenecks must be constantly identified and removed. One approach may be for affiliated scholars to sign Codes of Conduct while leaving room for their individual creativity or be asked to undergo courses in scientific method. Talent recognition and nourishment, besides the necessary ecosystem to mentor scholars and award achievement must be 


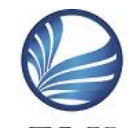

ELK

Asia Pacific Journals

www.elkjournals.com

put in place. In any case, ideological cronyism has no place in today's world, as this works against the principles of talent recognition and service to society. One more interesting possibility is to involve researchers from as many different nationalities and cultural backgrounds as possible into the gamut of historical research and research in allied disciplines, as this would provide some kind of an immunity from over-generalization and Western stereotypes, and bring obscure and hitherto poorly-researched paradigms into the academic mainstream. The globalization of science by itself therefore presents exciting possibilities that were formerly not envisaged, and if properly leveraged can facilitate a quantum leap in knowledge. This process must not be restricted to countries or regions such as the USA, Europe and India, but must include other regions such as China, Africa and South America as well. The effect of cultural mores on the direction and nature of scientific research and the quantum of scientific output is not yet well-understood or researched; yet the effects of multicultural approaches on scientific endeavour are likely to be stupendous. We may call this 'Globalization of science'.

\section{Stakeholder and scholar-defined objectives to drive the direction of historiography}

Thus, the list of Scholar-defined and Standard Objectives is to be used to determine the direction of research and the approach to be adopted for history-writing. This list can also be used to identify key or focus areas of research wherever possible or applicable. A prioritization would be necessary, and can be carried out based on the principles described in this paper such as OLA and SBA. Scholars must constantly introspect whether objectives have been achieved or not, and an evaluation by other scholars is also to be encouraged.

\section{Layered approach to study and presentation}

We also propose a layered approach as described below so as to ensure that the requirements of all stakeholders are taken into account and to make the process of research and history-writing more effective. Using this approach, a scholar can systematically verify whether all his objectives have been met or not, and can target his output more effectively to various stakeholders. This approach also permits an easy dialogue with various stakeholders. One more advantage of this approach is that it can accommodate varying approaches, if demanded by different stakeholders. In the real world however, the scholar's output may or may not be physically segregated into various layers, and the scholar may use his best judgment to decide what is 
appropriate under a given set of circumstances.

The layers proposed in this approach are:

\section{Research layer}

The research layer would comprise the topics that have been identified for research. The list of topics needs to be prepared after generation of objectives, discussion with specialists, identifying problems faced in the dissemination of knowledge to a general audience, and such topics need to be ordered on a scale of importance using the techniques explained in this paper. Topics may also be added based on a set of triggers i.e. discovery of new or hitherto unknown evidence. Thus, the direction of research may be determined based on a combination of a pre-determined plan and fortuitous events. Problems can be categorized on the basis of how vexatious they are, or the constraints or limitations they impose on various fields of study, or the extent to which key impede progress in various areas, (Opportunity Loss approaches and Social Benefit analysis) and a pro-active approach may be followed, taking all available evidence into account, and following scientific methods. If the scholar is aware that a topic is already being addressed by another scholar, or set of scholars it may be demoted in the list. All this would be necessary, and more so if there are time or other constraints. The research layer also yields a research or a scholarly output, subsets of which constitute the presentation layer; a no-holds barred approach or disclosure of all known or available information may be followed here, but must be presented in a manner that other specialists can use it or relate to it. Generating a respectable quantum of research output, and disseminating it to other scholars will be one of the key functions of a historian, as also will be a healthy collaboration with them. A quest for the continuous expansion of the body of historical knowledge would the key driver for historiography. A version history and working notes must also be maintained as a part of the research layer.

\section{Presentation layer}

The presentation layer is a subset of the research layer and consists of four subcomponents i.e. General Presentation layer, Student's and Academician's layer, Localized presentation layer and research layer. Each sub-component is expected to cater to a different audience, with a broad over-lapping area. As such, the presentation layer exists only as the sum total of its subcomponents, and otherwise does not have a locus standi of its own. The presentation layer would contain all aspects of the output of the research layer except details the researcher would not, in the normal course of events be required to share with others such as working notes or his internal version history. While the approach to be 


\section{2 \\ ELK \\ Asia Pacific Journals \\ $\underline{\text { www.elkjournals.com }}$}

followed may vary in each case, a key concept to be understood is that there can be no factual contradictions or inconsistencies across layers under any circumstances.

\section{General presentation layer}

The general presentation layer is used to present information to a non-specialized audience, and would be largely driven by requirements of the target audiences. This can comprise of the general public, the layman who may have an interest in history and some types of researchers as well. This will not however cover students and academicians.

\section{Student's and Academician's presentation layer}

The scholar must take great care in presenting information to this kind of an audience, which may be further subcategorized based on maturity, and as a rule, controversial aspects of history or untested hypotheses must be left out from this layer. If the scholar feels the audience is mature enough, such material can be added with qualifiers. This approach also permits bowdlerization or sanitization of information at this layer, and even encourages it under specific circumstances i.e. if it has no or limited historical value, may have other adverse effects such as the promotion of communal hatred, or if the target audience is not mature enough for it.
Examples of such material are more gory details of the Crusades, the Spanish Inquisition or the details of demolition of Hindu temples by Muslim invaders. This is another key principle in this paper, and may help maintain a modicum of communal harmony. Scholars may prepare guidance notes for academicians and teachers wherever required on various topics. Ideally, the scholars approach must be more fact-driven and less interpretationfocussed, but the scholar must keep in mind the maturity of the audience to achieve a healthy balance between the two.

\section{Localized presentation layer}

The local presentation layer is usually a subset of the student's presentation layer, or the general presentation layer, in some cases, and is used to present information to a local audience, and would be largely driven by requirements of the target audiences, and would take into account the unique requirements of the region. For example, the scholar may be required to address specific needs to the region such as the need to maintain communal harmony, religious fundamentalism etc.

\section{Specialist's presentation layer}

The specialist's presentation layer is usually a subset of the presentation layer and is used to present information to a specialized audience, and would be largely driven by requirements of the target 


\section{2 \\ ELK \\ Asia Pacific Journals \\ $\underline{\text { www.elkjournals.com }}$}

audiences, and would take into account the unique requirements of the target audience. This would however be a subset of the presentation layer and would not conflict with it in any way. It would usually contain more information than the general presentation layer, and would overlap with the localized presentation layer as well. The specialists layer would also comprise sublayers targeted at each class of specialists, and in extreme cases, may comprise of articles targeted at individual scholars.

\section{Discuss whether approaches meet objectives}

The author would then need modify his approaches, as required and continuously review the process of research and history writing, by adding more stakeholders and objectives, such that the field of historywriting is kept as dynamic as possible. This can be done by taking stakeholder feedback at frequent intervals.

\section{Footnotes explaining key concepts and neologisms in detail}

\section{Footnote 1: Constant quest for objectivity and accuracy}

A constant quest for objectivity and accuracy and an unwavering and a passionate quest for the truth should be the hallmarks of any competent school of historiography, in spite of limitations such as incompleteness of primary sources, reliance on secondary sources, the scholars own personality traits etc.

While it is unlikely that subjectivity of approach and variations in interpretation will ever die out, and whether the complete elimination of variations in interpretation will even be healthy, the long-term objective will be to minimize variances in perception and interpretation, and at least those arising from ideology-driven interpretations and lack of precision or accuracy in research. Myriad interpretations will exist as long as ambiguity exists and as long as ideologydriven interpretations exist. As we strive for perfection, such interpretations will inevitably fall by the wayside and die natural deaths. If wide variations and interpretation persist, historians must step in and carry out a root cause analysis. We suggest that this be made one of the key tenets of HBO. Dialectical approaches and reconciliation of contradictory evidence (we propose the terms FDARC or Formal Dialectical Approaches for the Resolution of Conflicts), CRCDE or Continuous Reconciliation of Contradictory Data of Evidence, and Reflective Equilibrium through role-swapping (RERS) are some of the tools we propose to resolve conflicts. The key principles in case of FDARC are (a) The party submitting a proposal is asked to present all his evidence in writing (b) This can be criticized by the opponent using proper scientific reasoning and methods (c) 


\section{2 \\ ELK \\ Asia Pacific Journals \\ $\underline{\text { www.elkjournals.com }}$}

The initial party can then respond using additional evidence (d) This process can continue until a higher state of understanding is reached (e) Unfair practices such as use of undue influence and pseudo-scientific approaches should not be allowed (f) an ombudsman, an umpire or an arbiter may be appointed, if required to initiate and oversee the entire process, including selection of parties. (g) All proceeds along with evidence must be maintained in writing. (g) Both parties must, in the natural world, support their own stand, and we may emphasize, as fervently and stridently as possible. The selection of the right parties, is of paramount importance, and their competence must be beyond the shadow of a doubt. We can also insist that the "Best person for the job" is selected. These requirements are a counter-weight to prevent frivolity of arguments. (h) Arguments without substance, or those driven by sophistry or polemics will not be encouraged. (i) Outright prima facie rejection of claims without scrutiny of evidence is not encouraged. (j) All claims made at different points in time may be subjected to this process; thus the process is expected to be centred on an issue; the parties must always bear in mind the fact that the objective of the exercise is to resolve issues and move towards a higher understanding. (k) This approach must always be complemented by a study of obloquy or public criticism, if any, of the scholar (l) The verdict, under no circumstances will be limited to outright acceptance and outright rejection. Various scenarios will need to be identified either upfront or during the process of debate and need to be added as outcomes of the final verdict. (1) Outright rejection will be used only as the last resort, and will be used only if the claim can be conclusively disproven. Ideally, the case will be marked as inconclusive unless conclusively disproven. (m) Scholars are strongly encouraged to improve the methodology itself. Thus, these techniques are a vast improvement over standard devil's advocacy techniques. In case of CRCDE, the key principles are (a) contradictory data or evidence must be aggressively sought, and such data or evidence is nothing to be afraid of (b) if contradictory data or evidence exists, the model or approach is over simplified (c) Reconciliation of contradictory data will always move us to a higher state of understanding (d) if contradictory data is left out from an analysis, a justification may be required. Contradictory viewpoints may however be left out, if not backed up by data, or if the methodology used by the other historian has been convincingly or comprehensively refuted by the historian in question. In case of Reflective Equilibrium through roleswapping (RERS), the scholar learns to put himself in the shoes of all other 


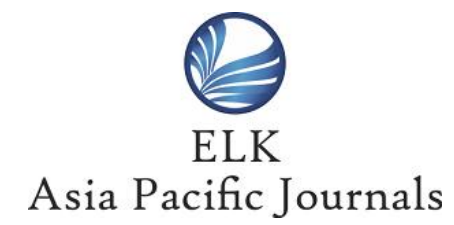

$\underline{\text { www.elkjournals.com }}$

stakeholders who would benefit from the work or be impacted by it, and does this one stakeholder at a time. He then tries to look at issues from the other party's point of view, or evaluate how he would react to it using that party's known ideological affiliations, dispensation, antecedents or other relevant information as a base. $\mathrm{He}$ documents his observations and then modifies his work accordingly, or generates new objectives. A key advantage of this approach would be that it would save time, effort and energy, and works in a field such as historiography where the other party may be unavailable or dead, and could be used in conjunction with other approaches. These approaches can be adopted in addition to other dialectical approaches such are those which were propounded by Hegel and reinterpreted by Marx, and other approaches such as Rawl's reflective equilibrium, standard Devil's advocacy \& Brainstorming techniques such as the Delphi technique and Edward De Bono's Six Thinking Hats. Dialectics also form the foundation of Ashtuller's TRIZ techniques.

Marxist historians in India have insisted that many interpretations are possible, and have harped on this ad nauseum. They have even unfortunately argued, whenever it has suited them, or their petty ends, that the 'Hindutva School' of historiography has also been allowed to exist since India's independence. This is bound to evoke suspicion in many quarters as if it were a vindication of their ideology-bound and dogma-driven approach and an earnest pleading for a public mandate to permit their ideology-driven approaches to continue even if there were inimical to science or scholarship. They have of course never moved towards a reconciliation or have never ventured beyond the confines of their dogma-driven approaches. Some basic principles such as examination of all data, whether amenable to a viewpoint or not, must also be followed under all circumstances as should also be a balanced and an ideology-free approach and one free of preconceived notions or predilections. A balanced approach must always be stressed and emphasized, and few would deny the fact that Marxist historians in India have overlooked this, as also have Hindutvadriven ideologues. As we have pointed out in an earlier paper, one kind of bias legitimizes every other kind of bias, and while Marxist historians may have has no malafide intentions per se, this kind of an approach permits their scholarship to be replaced by a more dangerous ideology like Hindutva in a generation or two. The fact that the average age of the top five Marxist historians in India as of 2015, was around 83 years speaks for itself. Thus, the obvious conclusions are (a) Marxist historiography in India cannot continue and is doomed to failure (b) It death can come about due to a variety of causes such as death of its practitioners, senility or old age (c) its 


\section{2 \\ ELK \\ Asia Pacific Journals \\ $\underline{\text { www.elkjournals.com }}$}

collapse may also be cataclysmic like the collapse of the Soviet Union and may be brought about by the takeover of the field by other ideologues. (d) Its collapse with be disastrous, as there is no credible alternative approaches to history, and a fossilizedapproach has ensured that textbooks have not been updated for decades. (e) Marxist historians are not even interested in combating Hindutva in the longer term. While they undoubtedly did play a major role in exposing Hindutva in the 2000's, and must be thanked for it, their long-term commitment to the healthy progress of science is under question; the reasons may not be difficult to seek: when an individual starts with a fundamentally wrong premise, and attempts no course corrections over a period of time, he loses a sense of direction, loses his purpose and may eventually cease to act in the interests of scholarship.

Wherever a reconciliation between varying or diametrically opposite points of view proves difficult, we would also recommend a back to the basics approach or CRBOK (Critical re-examination of entire body of knowledge) which essentially involves revisiting and questioning every assumption made by every scholar in the field and re-examining the entire corpus of scholarship or scientific knowledge critically. As this would, under normal circumstances, be difficult or timeconsuming, this may be encouraged under specific circumstances when a scholar believes a re-examination of basic principles or assumptions is warranted, and where assumption has been built upon assumption, causing a super-structure to be built on erroneous assumptions.

\section{Footnote 2: Insistence on hard or irrefutable evidence at all times}

One must emphasize the need for hard or irrefutable evidence and data at all times to back up all statements or claims. In certain cases, however a compromise is in the best interests of scholarship particularly if useful information is lost to the public if narratives are left out due to want of irrefutable data, and if such loss of potentially useful information is detrimental to society or other fields of study. This would count as a great loss to the world of scholarship. Scepticism is healthy, but cynicism beyond a point would work against the interests of scholarship. We insist that this be made one of the key principles of this paper, and will continue to insist that scepticism beyond a point would be unhealthy and would constitute a bias. As a result, this would automatically act against the interests of science and the promotion of scientific knowledge. In cases where risks are involved and the author feels his scholarship may not be infallible, qualifiers may be added, and the details of the risks involved with such interpretations may be laid bare to the public. In such cases, details such as the source of the data, and 


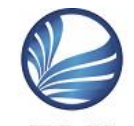

ELK

Asia Pacific Journals

www.elkjournals.com

methodology may be made public as necessary. We have proposed that various presentation layers be used to target different audiences, and such scholarship may be targeted only to the appropriate or specialized audiences, if necessary before a consensus can be forged. We would like to reiterate, that an over-emphasis on irrefutability of evidence is as great a crime as scholarship that is not backed by sufficient data as it would impede scientific progress and act against the natural process of hypothesis-building.

\section{Footnote 3: Only Evidence-based and objective revisionism is encouraged}

While revision of a body of work may be warranted as data expands, as new evidence is found, or if new interpretations need to be accommodated, the historian must guard against ideology-driven requests for revision, as were common among Hindutva ideologues in India in the 1990's and the 2000 's. However, some of their criticism against the then current historical models may have been justified as these were widely believed to have been outdated. However their well-known machiavellian techniques of using these as subterfuges to present other approaches with phantasmagorical attributes was extremely dangerous. Hindutva revisionists then stooped to very low levels such as falsification of evidence to further their own ideology, and one such instance was exposed by Michael Witzel of Harvard University, and Steve Farmer (Horseplay in Harappa, Frontline, 2000). One approach to thwart or pre-empt revisionism is to document limitations and criticism of current approaches thoroughly and meticulously and proceed to find solutions to all vexatious issues and problems within the ambit of mainstream scholarship itself, and on a prioritized basis, to nip revisionism arising from other sources in the bud and to prevent fools from rushing in. All new evidence arising from various sources has to be examined from an objective and dispassionate viewpoint, and changes must be brought about within the realms of mainstream historiography. Mainstream researchers must also learn to take all constructive criticism in their stride, and respond to it objectively. This is in addition to constant introspection. Of course, if this has to happen, all ideologydriven and shambolic or sclerotic approaches will need to be driven out from the purview of mainstream scholarship, and until this happens, mainstream scholarship will always be at a risk of being hijacked by people with vested interests. James McPherson, writing for the American Historical Association, describes the importance and importance of revisionism as

follows

"The 14,000 members of this Association, however, know that revision is the lifeblood 


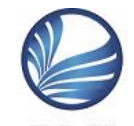

ELK

Asia Pacific Journals

www.elkjournals.com

of historical scholarship. History is a continuing dialogue between the present and the past. Interpretations of the past are subject to change in response to new evidence, new questions asked of the evidence, new perspectives gained by the passage of time. There is no single, eternal, and immutable "truth" about past events and their meaning. The unending quest of historians for understanding the past - that is, "revisionism" - is what makes history vital and meaningful. Without revisionism, we might be stuck with the images of Reconstruction after the American Civil War that were conveyed by D. W. Griffith's "Birth of a Nation" and Claude Bower's "The Tragic Era. Were the Gilded Age entrepreneurs "Captains of Industry" or "Robber Barons"'? Without revisionist historians who have done research in new sources and asked new and nuanced questions, we would remain mired in one or another of these stereotypes. Supreme Court decisions often reflect a "revisionist" interpretation of history as well as of the Constitution.

\section{Footnote 4: Distaste for ideology-driven approaches}

Acknowledgement of the fact that while human biases and prejudices may in large part be natural and cannot be entirely wished away with a magic wand, any healthy approach must seek to minimize and eventually work towards the reduction or elimination of any kind of biases whether personal or ideology-driven, other prejudices and non-objective approaches. While quantifying and trying to minimize personal biases and prejudices, a trade-off between what may be considered quixotic and unachievable given the nature of human behaviour and what should be enforced in the greater interests of society may be arrived at.

Scholar motives, for example, can be gauged by Identifying affiliation, tracing antecedents, carrying out a critical analysis of scholarship, evaluation during interaction with the scholar in question, perceived haughtiness or hubris, behaviour during the peer-review process for example, Refusal to review without assigning a reason, Rejection without a report, Ad hominem attacks, Does not follow epistemology, Diversionary tactics, Introduction of red herrings etc. Other characteristics of a pseudo-scholar are:

- Preference of political forums over scholarly forums for debate

- Ad hominem attacks as opposed to scholarly criticism- a test would be to evaluate how much of a claim still stands if ad hominem attacks are eliminated.

- Selective use of data

- Does not consider contradictory data 


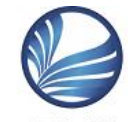

ELK

Asia Pacific Journals

$\underline{\text { www.elkjournals.com }}$

- Does not take into account criticism of ideology or approach over a period

- A scholar substitutes objectiveanalysis for Interpretations

- Politicking and ideology-driven interpretations take precedence over objectivity

- Scholar discourages multidisciplinary approaches

- Self-aggrandisement and use of titles such as 'expert', 'worldfamous researcher' etc. with an ostensible view to mislead the public.

- Grandiloquent announcements in the popular press in lieu of robust and methodical research

The following additional principles must also be borne in mind

- An acknowledgment of the fact, that in addition to human fallibilities, ideology driven approaches slow down the progress of science even further also is crucial to our approach.

- A scholar cannot be absolved of his guilt as he has permitted competing ideologies to flourish.

- Devil's advocacy can be encouraged in specific contexts only: substitution of subjectivity and personal opinion with objectivity and irrefutability has to the long-term goal.

Different types of ideological affiliations and proclivities in India include Hindutva, Dravidian nationalist, Dalit and lower caste Hindu, Colonial or imperialist, Marxist, Colonial-Marxist-imperialist nexus, African supremacist approaches impacting Indology, Dalit-Dravidian-African supremacist nexus, Indo-centric approaches, Euro-centric approaches etc.

\section{Footnote 5: GOWEST approach or Goals, Opportunities, Extraneous factors, Threats, Strengths and Weaknesses approach for DPPF techniques and Deep Historical Analysis (DHA)}

From the point of view of DPPF, goals would be the goals that have been identified for a society by the government, other institutions and organizations, other scholars etc., or based on any known areas of improvement. These could be long-term goals, or long-term goals. Some may be localized, others may be applicable beyond the area in question. This can be used to generate a list of areas of improvement which will eventually culminate in a plan to augment the positive forces, and reduce the negative forces. The already existing positive forces through which goals can bear fruit will also be identified. This approach will also automatically identify the negative forces. The next step would be 


\section{2 \\ ELK \\ Asia Pacific Journals \\ $\underline{\text { www.elkjournals.com }}$}

to identify opportunities that exist or the opportunities the society is missing out on. These can either be long-term or short-term. This can also be used to generate a list of areas of improvement which will eventually culminate in a plan to augment the positive forces, and reduce the negative forces. Existing positive forces through which opportunities can be attained will also be identified. Likewise, negative forces will also be identified. Extraneous factors could be factors like global warming, oil prices increases etc. which the society may not have full control, but can at least be partly addressed. This can again be used to generate a list of areas of improvement which will eventually culminate in a plan to augment the positive forces, and reduce the negative forces. Similarly, this can be used to identify already existing positive and negative forces. Strengths of a society can be identified based on a Deep Historical analysis performed by the historian or based on analysis of recent data. These can be used in the process of goal-setting, which can be used to identify more positive forces and mitigate the negative forces. Weaknesses of a society can also be identified by a historian based on a deep historical analysis or analysis of recent data. These can be used to identify areas of improvement and set more goals which will increase the positive forces and reduce the negative forces. The premise of the approach is that while the goals, opportunities, strengths, weaknesses, positive and negative forces can change from time to time and from context to context, the underlying concepts of this approach do not, and that the scholar is free to use this approach in almost any context within the DPPF framework. Another underlying principle of the DPPF framework is that man is the only animal which can change its collective destiny through individual or collective freewill, and can bring about social change and radical changes to society without changing the innate nature of man. No other animal has the capacity to do this. This, according to this approach, is the key and most important differentiating factor between man and other animals. With almost no modification, this approach can also be used for any kind of Deep Historical analysis (DHA). In such a case, positive and negative forces in a society in a given point in time need to be understood and a Root Cause analysis needs to be carried out using the tools used in this paper, or other approaches. These be traced to (a) strengths of the society (b) weaknesses of the society (c) Extraneous factors, and this approach can be further used to analyse society. (d) Goals here would be the motivating factors of an individual or a set of individuals. (e) Threats here would be the extraneous threats or limitations imposed on the individual or the individuals, causing any aberrations, or modification in behaviour, 


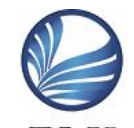

ELK

Asia Pacific Journals

$\underline{\text { www.elkjournals.com }}$

and ultimately determining his or their actions. (f) Opportunities here, would shape goals, and this approach can, more importantly be used to identify lost opportunities which can then be taken by for an RCA, linking them to strengths and weaknesses. This approach can be used for both societies and individuals. A formal Cause and Effects analysis then needs to be prepared for both the positive and the negative forces (FCEA) which must be prepared with a great deal of care, and always guarding against oversimplification or superficial analysis. The next step in the case of DPPF would be a Formal Plan for the Mitigation of Negative forces (FPMNF) - This is not required in case of DHA. The final step would be a Formal evaluation and Documentation of learnings (FEDL) which can then be used to predict future events in the case of DPPF, and can be an invaluable aid for other scholars and historians in the case of DPPF and DHA. Thus, with modifications, and as shown above, it can be used both for DPPF and a Deep Historical analysis, and can easily be extended to cover other areas such as Cliometrics. This approach should be seen as a vast improvement even over ideas put forth by the Annales School and other schools, and can become an allencompassing tool and a tool with wideranging ramifications.

\section{Footnote 6: Encourages critical analysis of religion}

We classify approaches towards religion into the following three categories from the point of view of our approach

a. The religious fundamentalists approach or an ideologically-driven discrimination between religions. Examples of ideology-driven approaches are presented as a part of this paper. Those who adopt an ideologically-driven discrimination between religions may not admit to doing so; in addition they may also be falsely accused or bias or prejudice. All accusations of bias and prejudice must be quantified and bias must be proven to be systemic, inherent or well-entrenched. All concerned parties may need to enter into a dialogue, and for this, the approaches in this paper may be followed. The ill-effects of such bias or prejudice from the point of view of scholarship may also be documented along with its ill-effects on science, scientific endeavour, and the counter-reactions it is likely to produce.

Examples of ideological bias or ideological communalism of which religion forms a part are given below. While it must be admitted that this list is partial to India, its principles are more or less universal across the globe, and must be fought 


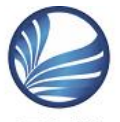

ELK

Asia Pacific Journals

$\underline{\text { www.elkjournals.com }}$

if it conflicts with objectivity. If this happens, and objectivity is systemically or routinely compromised, it qualifies as a pseudo-science.

- Hindutva disdain for the Mughal chapter in Indian history

- Hindutva tendency to glorify the Indian past

- The over-arching Hindutva obsession about the origin of the 'Aryans'

- The Hindutva contempt for the rise of Buddhism

- Bias arising out of Marxist preference for periods where the caste system was not on force or the Marxist notion that religion can be wished away or forgotten through suppression of specific periods in Indian history.

- Anti-communist bias in capitalistic societies

- Anti-capitalistic bias in communist societies

- Anti-Dalit viewpoint of Hindutva historians

- Anti- upper class view point of Dalit historians

- Pro-Semitic tendencies of Hindutva ideologues
- Anti-Semitic tendencies of Marxist ideologues

- Indo-centric bias among Indian scholars

- Euro-centric bias among European scholars

- The tendency of Marxist scholars in India to adhere to colonial constructs

- The Dravidian nationalist's view point

- Obfuscation through selective pragmatism cannot be used to exonerate such parties from guilt.

b. The secularists approach: This is a wellintentioned, if somewhat naïve approach to religion. It assumes, and in most cases, wholly in good faith, that all faiths, religions, doctrines and ideologies are equal and ought to be respected equally. A key aspect of this approach is to ensure that sentiments of different religious groups are not hurt. Such approaches may work well in the short to medium term and help establish a modicum of communal harmony. However, this approach fails to take into amount the fact that all religions are not equal and different religions contain differing amounts of good and bad. It does not seek to eliminate the ill-effects of religion from society. This is notwithstanding the fact that there have 


\section{2 \\ ELK \\ Asia Pacific Journals \\ $\underline{\text { www.elkjournals.com }}$}

been many efforts to reform religion in the past, many of which have met with a reasonable quantum of success. A key reason for adopting the aforesaid approach in earlier times was perhaps to maintain a semblance of communal harmony, and the fact that a critical analysis of religion may have been beyond the capability or purview of local historians in various societies.

c. The critical analysis approach: The critical analysis approach calls for a critical analysis of all religions against the backdrop of the twenty-first century and encourages new areas of hermeneutical study devoid of any religious or ideological underpinnings. This paper suggests that this would be the way forward, and must ideally be carried out as subtly and effectively as possible without offending the feelings of any community. All religions and religious dogmas are unequal; not acknowledging this would be fallacious. Equating Islam and Jainism or Hinduism and Christianity for example, would be an exercise in futility as these are all very different ideologies or philosophies which originated under different circumstances or were shaped by different forces at different points in time, or may contain different philosophies that are either compatible or incompatible with modern notions of civility and decorum. This must not be construed as quixotism; it is, the crying need of the day. This is a process that may take several decades, but it must be initiated nonetheless, and scholars would be well-advised to tread cautiously, and set in motion a process that would eventually mitigate the illeffects of religions. A critical analysis must not only encompass hermeneutical study but also third party interpretations of religion, an analysis of fringe elements and cults in any religion, and their impact on society so that an overall assessment of a religion can be made. However, it would be natural for a scholar to adopt a localized approach or one driven by local considerations. For example, an Indian scholar would not be expected to take up the analysis of a religion that under ordinary circumstances has no relevance in India.

\section{Footnote 7: Innovative approaches to bring scientific awareness to the masses}

Another interesting but potentially potent tool available at the hands of the innovative historian is the quest to newer methods to bring scientific thought and awareness to the masses. This can be done because of the gradual disappearance of the boundaries between history and the various sciences. For example, educationists have, and with full reason, cried hoarse about the inclusion of theories not backed by substantive 


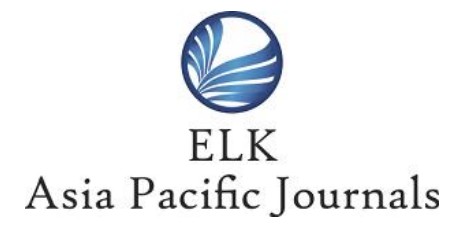

$\underline{\text { www.elkjournals.com }}$

underlying evidence, such as the Theory of Intelligent Design. While they deserve to be applauded for such initiatives, it would also be instructive to explore the underlying causes for the dogged persistence of such beliefs in the human psyche. A key reason is that scientific versions of history and scientific theories of evolution have not been fully ingrained in the human psyche, and are not counted on in the daily experience. This is critical in countries like India, where tradition reigns supreme, and warped and popular misrepresentations of history have existed since millennia. What is necessary is to ensure that the origins of Indian culture are logically and scientifically explained to readers, and answers to all questions students ask are available in mainstream literature, such that alternative views are eventually left by the wayside. This approach in itself is likely to have a major positive impact on the Indian psyche, and this itself can be a major weapon in the fight against superstition and blind faith, can do what Charles Darwin's theory of evolution did for the west one and a half centuries ago, and can even be construed as the foundation of what we called "Scientific progress at the speed of light". As usual, Marxist approaches are utterly at odds with the basics or commonsense, as they do not take into account the working of the human psyche, and throw up counter-reactions. Marxist historians get the wrong end of the stick always, and as such, it is the duty of other scholars to warn them that they are acting against national interests and the interests of science and scholarship, eventually working towards a quantification of ills associated with all ideologies without prejudice so that future generations of students and scholars can be warned accordingly. Another innovative approach would be to combine local history with international history and various sciences and milestones in human endeavour, besides those dealing with the origin or development of various technologies such that the story of human endeavour is brought out as a cogent and a logical whole, nipping all forms of nationalistic-history writing automatically in the bud. A still more innovative approach would be to combine this with standard theories of human evolution and indeed the evolution of all species over hundreds of millions of years, given our greatly enhanced understanding of the earth's past, bringing about a syzygy in various fields of science. We say this because awareness of basic science is extremely low even among the better educated; an anachronistic approach to learning may be partly to blame for this; the layman in India, with his halfbaked knowledge of mainstream theories he usually does not believe, and a lack of even a basic knowledge of human and natural history is then a prime target for people with vested interests who want to deceive and exploit him or turn him around to their point 


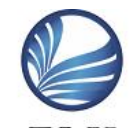

ELK

Asia Pacific Journals

$\underline{\text { www.elkjournals.com }}$

of view. Over the past couple of decades, astronomers have detected nearly two thousand planets around neighbouring stars other than our sun. Our Milky Way galaxy alone, with over 400 billion planets (there are millions of galaxies like the Milky Way) may contain between 400 billion to two trillion planets, and using a conservative application of Drake's equation, several tens of thousands of intelligent civilizations, perhaps much more. This figure has to be multiplied by the number of galaxies to arrive at the number of intelligent civilizations in the universe. These theories are a far cry from Biblical and Hindu theories of creationism, and to state the very, very obvious, are wholly incompatible with one another. It would also be extremely obvious that older theories were but manifestations of man's limited knowledge at the time. Without delving into controversial aspects such as the existence of 'God', a term which perhaps has not even been satisfactorily defined, thereby rendering any debate meaningless, the historian can make an attempt to integrate his science with allied sciences, picking up the threads from where scholars of other sciences have left them off, to present a complete picture to the untrained layman. While most historians would consider such an effort to be wholly outside their gamut, this would unlikely to be an exercise in futility, and the rewards in terms of raising the general levels of knowledge and awareness in the common man and battling superstition and blind faith may be immense and gratifying. This is likely to have ripple-effects on the wellbeing of societies as a whole, and cults, sects and religious dogma may eventually be consigned to the rubbish-heap of history.

\section{Conclusion}

This approach is designed to avoid the perils and pitfalls of ideologically-driven approaches to historiography such as those adopted by religious fundamentalists and to quantify and eliminate biases and prejudices of all kinds. It also seeks to generate robust methods for historical research and make the role of the historian more rewarding and fulfilling, and to ensure that the expectation of a historian from all stakeholders are met, and to ensure that the historian acts in the interests of society and the education system. It also consists of checks and balances at every level, and is designed to augment the pace of research in the Twenty-first century. This approach is born out of the decade-long experience the author has had in historical research including dealing with very complex issues, and experience in publication in peerreviewed journals. The author would be glad to receive any feedback on the approach followed and will gladly address any concerns or criticisms. 